\title{
Etika Legislatif untuk Wakil Rakyat
}

\author{
Legislative Ethics for Honourable Members
}

Rais Yatim*

\begin{abstract}
Abstrak
Kertas ini mengesyorkan anggota legislatif yang terdiri daripada Dewan Rakyat dan Dewan Negara serta Ahli-Ahli Dewan Undangan Negeri (ADUN) dibedung oleh suatu Etika Legislatif. Perihal ini harus diwajibkan memandangkan lantaran pengaruh negatif sudah mula bertapak dalam kalangan ahli-ahli Yang Berhormat. Jika trend ini tidak diawasi, Parlimen dan Dewan Undangan Negeri (DUN) akan muncul sebagai institusi gerhana nilai dan budi. Masa depan negara bangsa harus dijamin keutuhannya. Perkara ini boleh dicapaijika sifat dan kelakuan anggota legislatif Malaysia dibimbing secara positif.
\end{abstract}

Kata Kunci: Etika, Legislatif, Keluhuran Undang-Undang, Peraturan Am, Peraturan Mesyuarat

\section{Abstract}

This paper recommends that members of the legislature consisting of the House of Representatives and the Senate, as well as Members of the State Legislative Assembly (ADUN), be swaddled by a Legislative Ethics. This matter should be made compulsory considering that negative influence has begun to take root among the Honourable Members. If this trend goes unchecked, the Parliament and the State Legislative Assembly (DUN) will soon emerge as institutions eclipse in values and virtues or will be seen as institutions with eroding values and virtues. The future integrity of the nation must be assured. This can be achieved if the character and conduct of the Malaysian legislature are being guided in a positive manner.

Keywords: Ethics, Legislative, Rule of Law, General Orders, Standing Orders

* YB Tan Sri Dato' Seri Utama Dr Rais Yatim is the President of the Senate, Parliament of Malaysia. Email: ypdn@parlimen.gov.my 


\section{Pengenalan}

Kertas ini membicarakan pentingnya etika legislatif atau etika khidmat bagi semua Ahli Yang Berhormat yang bergelar YB Wakil Rakyat di semua Dewan Perundangan - Parlimen dan Dewan Undangan Negeri (DUN). Usaha ini juga adalah sebagai instrumen panduan awalan, rujukan dan pembidang disiplin interaksi melalui nilai, kaedah berinteraksi dan tatacara kelakuan di lapangan. Instrumen panduan ini bukan sahaja berkaitan dengan kelakuan atau tingkah laku anggota dewan legislatif semasa Parlimen bersidang, semasa berbahas atau bertikam lidah, tetapi juga sebagai rujukan tentang panduan dan langkah-langkah pencegahan perwatakan negatif di dalam dan di luar dewan.

Seseorang YB Wakil Rakyatitu terdedah kepada pelbagai risiko kritikan dan cemuhan, tanggungan sosiopolitik apatah lagi beban konflik hidup yang mencabar di lapangan dan di tengah-tengah masyarakat yang dikhidmatnya. Ahli Parlimen (di Dewan Rakyat dan di Dewan Negara) dan Ahli Dewan Undangan Negeri (ADUN) di 13 negeri boleh dirumus sebagai insan pimpinan yang tinggal di dalam rumah kaca - perbuatan fizikal mereka jelas tampak kepada pemerhati dan pengamatan rakyat jelata.

Kertas ini disediakan sebagai punca kesedaran awal memandangkan Parlimen dan dewan-dewan perundangan negara peringkat negeri telah terserlah kepada kritikan dan pandangan negatif susulan tingkah laku dan gelagat ahli-ahli YB semasa berkomunikasi, berhujah dan berdebat di Dewan Rakyat khasnya. Amat buruk padahnya apabila anak-anak remaja, para pelajar dan masyarakat amnya melihat gelagat sombong, kasar bahasa dan piel tiada budi bahasa dalam kalangan segelintir pemimpin yang bergelar Yang Berhormat atau YB. Umum kerap melihat keadaan kurang menyenangkan apabila menyaksikan gelagat 'bebas cakap - bebas bantai' yang diperagakan di Dewan Rakyat - dewan legislatif tersohor tanah air. Pemimpin YB kita ini jugalah yang sering mengajak rakyatbersatu padu, mencapai kemajuan dan menyeru supaya menyokong pimpinan dan parti mereka demi masa depan bangsa dan tanah air. Harapan rakyat untuk beroleh pimpinan melalui teladan akan menjadi amat sukar diwujudkan dalam kalangan masyarakat jika kecenderungan negatif seperti ini berterusan dilihat di kaca televisyen serta paparan media sosial.

Hal ini sering menjadi tular dengan gelagat pimpinan legislatif yang kasar bahasa dan keperibadian kontroversi. Keadaan begini mungkin disebabkan oleh faktor ketiadaan latihan sebagai Wakil Rakyat yang 
sesungguhnya amat kurang beroleh bimbingan dan latihan selepas kemenangan Pilihan Raya Umum (PRU) atau Pilihan Raya Kecil (PRK).

Mesti dicari jalan supaya gah tindak-tanduk negatif anggota legislatif ini dinyahkan daripada kamus perjuangan jika kita masih serius untuk mewujudkan masyarakat penyayang, toleransi dan berbudi tinggi. Tulisan ini memuatkan beberapa syor pokok ke arah mewujudkan budaya tinggi sebagai asas tamadun nasional menerusi saluran legislatif.

Perlu dirakamkan penghargaan bahawa ahli-ahli YB tanah air kita semenjak 1955 hingga kini secara kolektif telah banyak menyumbang jasa dan khidmat kepada rakyat dan negara Malaysia. Sektor legislatif negara kini yang diwakili 222 orang di Dewan Rakyat, 70 di Dewan Negara dan sekitar 600 orang ahli Dewan Undangan Negeri (ADUN) kesemuanya mempunyai rekod sumbangan membina negara yang sukar dihitung dan tidak upaya diberi nilai satu persatu. Namun di samping aluan penghargaan itu tersua jua beberapa gading yang retak dan bumi yang tidak ditimpa hujan. Justeru, bersama-sama kita jelujuri dan tampal kain yang koyak, tegakkan semula tiang nan condong, apungkan kembali teras nan terendam.

\section{Peristiwa kasar bahasa dan salah nilai}

Berikut diimbas kembali beberapa peristiwa gelagat kasar bahasa dan songsang nilai di Dewan Rakyat. Pada tanggal 21 November 2016, anggota dari Pasir Salak mengungkapkan, 'Yang Berhormat Seputeh ini kek, kek, kek, kek ni fasal apa? The only woman with a "kok" is in Seputeh'. Ungkapan itu walaupun mencetuskan ketawa jelas menimbulkan reaksi riuh-rendah. YB dariSeputeh memberi reaksi spontan, 'Ini Menteri yang tak ada tamadun punya'.

YB Ipoh Barat lantas menyelar, 'Tuan Yang di-Pertua unparliamentary word, suruh dia tarik balik. Itu sexist remark'. Kemudian setelah banyak lemparan kata-kata rentas Dewan, suasana lintang-pukang terus wujud. Tiba-tiba keluar satu suara, 'Sial punya Menteri'. Ahli dari Pasir Salak lantas membelasah tanpa menyorot kepada Timbalan Yang di-Pertua Dewan, 'Kepala otak engkau'. Tanpa perlu analisis, jelaslah Dewan Rakyat sudah jadi gelanggang bantai-membantai kata. Keadaan hirukpikuk memakan masa lama dan di luar kemampuan Timbalan Yang di-Pertua berbuat sesuatu.

Peristiwa kedua berlaku pada 7 Ogos 2018, YB dari Kinabatangan dalam reaksi di luar dugaan terhadap beberapa celahan termasuk daripada Ahli Puncak Borneo, Padang Serai dan lain-lain mengeluarkan 
kata-kata kasar dan bersifat biadab. ${ }^{1}$ Beliau lantas menggunakan istilah 'Tindakan kepala bapak mu lah' dan kemudian 'mencarut empat huruf' dalam bahasa Inggeris. ${ }^{2}$ Timbalan Yang di-Pertua yang cuba meredakan keadaan hiruk-pikuk semasa itu tampak kurang berjaya mendamaikan lonjakan emosi dan laungan suara tinggi daripada pelbagai penjuru dewan mulia itu. Ungkapan mencarut itu jelas kedengaran dalam rakaman video Dewan Rakyat.

Pada 9 Ogos 2018 di bawah tajuk 'Penggunaan Perkataan Kurang Sopan di Dalam Dewan', Tuan Yang di-Pertua ${ }^{3}$ memaklumkan kepada sidang:

Tanpa dipastikan kenyataan tersebut ditujukan kepada siapa, YB Kinabatangan terus menjerit menggunakan perkataan mencarut dan mengulanginya sekali lagi menyebabkan beberapa Ahli bangun membantah...saya ingin menyatakan sekiranya tingkah laku yang sama diulang, YB Kinabatangan akan dikeluarkan dari Dewan yang Mulia ini dengan serta merta untuk satu tempoh yang diperuntukkan di bawah Peraturan Mesyuarat $44 .^{4}$

Pada 4 April 2019, Ahli dari Tanjung Karang membuat ucapan yang sama sekali bersifat luar biasa dari segi keluhuran undang-undang. Ucapannya berkaitan dengan perbuatan yang seharusnya dianggap salah atau berunsur jenayah. Beliau menzahirkan pandangannya:

... mencuri tidak salah, tahu? Apabila kena tangkap itu baru salah. Naik motor tidak ada topi keledar tidak salah. Apabila polis tahan baru jadi salah ...

Pendapat umumnya itu menimbulkan reaksi hangat yang kurang menyenangkan - seolah-olah YB itu senang dengan kecenderungan jenayah justeru mungkin menggalakkan perbuatan yang menyalahi undang-undang. Semua peristiwa ini diketahui umum kerana siaran langsungyang dibekalkan kerajaan. Gambaran daripada siaran langsung

1 Kata-katanya: “Kepala bapak mu lah", lihat DR Deb 7 Ogos 2018, Bil.14.

2 Klip videonya ada dalam simpanan Bahagian Rekod Dewan Rakyat 2018.

3 Yang di-Pertua Dewan Rakyat ketika itu YB Tan Sri Mohamad Ariff Md Yusof.

4 PM 44(2) Dewan Rakyat menetapkan, "Pengerusi hendaklah memerintah manamana Ahli yang berkelakuan tidak senonoh atau melakukan perbuatan yang menghina Majlis Mesyuarat atau terus tidak mengendahkan kuasa Pengerusi keluar dari Majlis Mesyuarat bagi tempoh tidak melebihi 10 hari dan Ahli tersebut hendaklah dengan serta-merta keluar dari Majlis Mesyuarat..."

5 DR Deb 4 April 2019, Bil. 16. 
Radio Televisyen Malaysia (RTM) amat ketara bahawa di Dewan Rakyat berlaku kekecohan dan huru-hara persidangan; pemimpin menganjurkan konsep baharu dalam usaha menilai penjenayahan. Dewan Legislatif sepatutnya aman damai dengan hujah tersusun serta akumen intelek yang tinggi.

Tindak-tanduk politisyen, ${ }^{6}$ iaitu sebagai wakil rakyat dan sebagai pemimpin masyarakat berkaitan belaka dengan jaluran hidup rakyat secara langsung. Setiap Ahli Parlimen atau DUN merupakan pimpinan contoh dalam khalayak kawasan masing-masing. Lantaran inilah timbul keperluan agar anggota legislatif di semua peringkat mempunyai kod etika sendiri yang mengandungi petua, bimbingan dan syarat-syarat asas bagi menjalankan khidmat sebagai Yang Berhormat wakil rakyat yang diberi gaji serta elaun bersumberkan wang rakyat. Terbaik sekiranya semua wakil rakyat yang bergelar YB atau Yang Amat Berhormat (YAB) menggalakkan dan mempromosi amalan berbudi bahasa dan mewujudkan urus tadbir integriti yang bertauliah walaupun ada dalam kalangan mereka yang pada hakikatnya memang sedia berhemah tinggi sebagai Menteri, Timbalan Menteri, Setiausaha Politik dan sebagainya. Pada masa sama, mungkin ada pula yang mendengus lalu berkata bahawa mereka sudah lama makan garam, justeru tidak perlu dilatih tubi lagi oleh sesiapa. Berbalik kita kepada kebenaran falsafah: lagikan buluh tua boleh dilentur, inikan pula insan yang masih bercita-cita tinggi. Dalam konteks inilah Etika Legislatif yang dibentangkan ini diketengahkan.

\section{Dikotomi ketidakwajaran dan kesalahan}

Sistem perwakilan rakyat di Malaysia terbahagi kepada tiga peringkat: pertama, wakil rakyat di peringkat negeri yaknidi DUN% ; kedua, di Dewan Rakyat dan ketiga, Dewan Negara (Senat) ${ }^{8}$. Perwakilan di peringkat negeri atau DUN ditadbir urus di bawah kawalan Perlembagaan 13 Negeri masing-masing, sementara wakil rakyat Persekutuan dikawal di bawah Bab 4 Perlembagaan Persekutuan. Istilah wakil rakyat membawa pengertian calon-calon yang berjaya dipilih melalui sistem pilihan raya

6 Penulis lebih cenderung menggunakan istilah politisyen daripada politikus atau ahli politik. Politikus, tiruan dari Indonesia, menyelitkan erti tetikus atau menikus justeru menimbulkan sifat curi makan, sorok-sorok dan tidak boleh dipercayai; ahli politik pula terlalu am erti dan implikasinya. Walau bagaimanapun istilah ini belum dalam penggunaan rasmi lagi.

7 Istilah popularnya Dewan Undangan Negeri atau DUN.

8 Di bawah penentuan Perkara 44 hingga 69 Perlembagaan Persekutuan. 
lima tahun sekali atau mengikut tempoh-tempohyang ditentukan dalam jangka masa maksimum lima tahun bagi sesuatu tempoh berkenaan di peringkat negeri dan Persekutuan. ${ }^{9}$ Dalam sejarah tanah air belum pernah wujud sesuatu kerajaan negeri atau Persekutuan yang durasi sahnya genaplima tahun walaupunundang-undang menentukanjangka hayat lima tahun bagi kuat kuasa legislatif negeri dan persekutuan. ${ }^{10}$

Dalam jangka masa lima tahun seseorang itu bergelar Yang Berhormat sebagai wakil rakyat, sama ada sebagai ADUN atau Ahli Parlimen, individu pilihan rakyat ini berkhidmat sebagai wakil kepada rakyat di seluruh kawasan pilihan rayanya. Dari segi idealnya harus dihalusi erti seseorang yang menjadi atau terpilih sebagai wakil rakyat. Seseorang wakil rakyat DUN atau Parlimen bergelar YB ialah seseorang yang dihormati, yang terhormat lantaran sahsiah dan budi pekertinya yang baik dan yang berkhidmat selama tidak lebih lima tahun di kawasan legislatif masing-masing.

Ada beberapa keanehan dalam sistem perwakilan legislatif rakyat sama ada di peringkat Persekutuan (Parlimen) ataupun di peringkat negeri(DUN). Di Dewan Rakyat ada 222 anggota yang mewakili kawasan Parlimen sejumlah itu pula; di Dewan Negara 70 anggota mengikut agihan 40 Senator lantikan Yang di-Pertuan Agong, dua Senator bagi sesebuah negeri, dua dari Wilayah Persekutuan Kuala Lumpur dan seorang dari Labuan, ${ }^{11}$ dan di seluruh DUN di Malaysia sedia ada sekitar 600 angggota. ${ }^{12}$ Kesemua mereka ini diberi gelaran Ahli Yang Berhormat. ${ }^{13}$ Salah satu persoalannya ialah; Mengapakah mereka tidak tertakluk di bawah satu tatacara atau etika perkhidmatan? Para wakil rakyat ini bebas berurusan dan bertindak dalam urusan hidupnya sebagai YB wakil rakyat.

9 Istilah wakil rakyat tiada terdapat dalam Perlembagaan Persekutuan atau Negeri. Ia hanya terma yang suai manfaat popular di kalangan rakyat dan media.

10 Lihat Perlembagaan Persekutuan, per 55(3).

11 Perlembagaan Persekutuan, per 45.

12 Perlembagaan Persekutuan, per 44 dan 45.

13 Panggilan Yang Berhormat atau YB berasal dari gelaran perwakilan legislatif Inggeris Honourable. (biasa dipendekkan kepada Hon.) Misalnya jika individu John Smith dipilih dalam pilihanraya The House of Commons di United Kingdom Britain, beliau dipanggil sebagai The Honourable Mr John Smith atau jika dalam mesyuarat House of Commons (yang setaraf dengan House of Representatives atau Dewan Rakyat di Malaysia dan lain-lain Dewan Legislatif di Negara-negara Komanwel). 


\section{Ketiadaan kesamarataan aplikasi undang-undang}

Dalam pada itu terdapatbeberapa muslihat yang memerlukan penjelasan atau justifikasi. Bolehkah seseorang wakil rakyat Parlimen, misalnya, berniaga atau menjalankan profesionnya secara yang mendatangkan pendapatan sendiri yang dari segi hadangan perlembagaan berupa 'jawatan berpendapatan'. ${ }^{14}$ Dalam Perlembagaan Persekutuan, seseorang Ahli Parlimen dilarang menjalankan perniagaan tetapi umum mengetahui mereka yang berbuat sedemikian ramai bilangannya, malah secara terbuka menjadi Pengerusi badan-badan perniagaan korporatGLC (Government Linked Companies) yang berpendapatan lumayan. Tidakkah ini bercanggah dengan Perkara 48(1)(c) Perlembagaan Persekutuan yang jelas melarang seseorang YB Ahli Parlimen sebagai peniaga atau berjawatan yang mendatangkan pendapatan? Justeru, persoalan sebabmusabab tidak diambil tindakan oleh Parlimen menjadi satu tamparan kepada Parlimen sendiri sebagai sebuah institusi berasingan kerajaan dalam umpamaan tali tiga sepilin tetapi berasingan pilinan masing-masing - yakni Parlimen, Eksekutif dan Kehakiman? Menjadi suatu kehairanan, sementara prinsip rule of law (keluhuran undang-undang) - konsep legasi A.V. Dicey. ${ }^{15}$ Konsep asingan kuasa dan fungsi ini telah menjadi batu asas atau foundasi tamadun urus tadbir dunia sejagat termasuk negara-negara Komanwel sampai kehari ini. Bagaimanakah peruntukan Perlembagaan ini terbiar mendayuskan keutuhan perundangan itu sendiri? Hal ini mungkin disebabkan oleh konsep dan prinsip asingan kuasa serta fungsi inilah agaknya masing-masing entiti tali tiga sepilin ini enggan mengambil tindakan. Ada pihak menganggap bahawa kata pemutusdalam halsepertiiniadalah dibawah kuasa mahkamah; ada pula yang beranggapan hal ini muktamad di bawah bidang kuasa legislatif sendiri. Hujah mutakhir ini terdapat pada Perkara 53 Perlembagaan Persekutuan yang memperuntukkan:

Jika berbangkit apa-apa soal sama ada seseorang ahli Majlis Parlimen telah hilang kelayakan menjadi ahli, maka soal itu hendaklah diputuskan oleh majlis itu dan keputusannya adalah muktamad.

14 Di bawah Perkara 48(1)(c) Perlembagaan Persekutuan seseorang Ahli Parlimen itu hilang kelayakannya jika 'ia memegang sesuatu jawatan berpendapatan'.

15 Nama penuhnya Albert Venn Dicey, penteori dan pengasas konsep keluhuran undang-undang British yang terkenal melalui bukunya Introduction to the Study of the Law of the Constitution (Oxford University, 1886). 
Dari bahasa terang dalam peruntukan itu jelaslah bahawa Parlimen berkuasa penuh di atas status seseorang ahlinya jika timbul waham atau syak wasangka tentang status keahlian. Namun, terdapat beberapa kes yang dibawa ke mahkamah berkaitan dengan kekeliruan denda yang 'tidak kurang daripada 2,000 ringgit' di bawah Perkara 48(1)(e). ${ }^{16}$ Justeru, jika seseorang ahli YB itu didenda RM2,000 sahaja atas sesuatu kesalahan; Bagaimana kedudukan hak ahli itu? Amat baik sekiranya isu yang timbul daripada kes seperti ini dimuktamadkan pengurusannya oleh Parlimen sendiri lantaran kuasa yang ada pada Perkara 53 boleh menyelesaikannya. Sebaliknya, jika seseorang Ahli Parlimen disabitkan suatu kesalahan oleh mana-mana mahkamah di Persekutuan dan dihukum penjara selama tidak kurang daripada satu tahun atau didenda tidak kurang daripada RM2,000 dan tiada mendapat ampun, anggota itu tidak harus diiktiraf hilang kelayakan sebagai Ahli Parlimen di sisi undang-undang. Pandangan ini mungkin kandas apabila seseorang YB itu sabit kesalahan mana-mana jenayah lazim seperti rasuah, pecah amanah dan lain-lain.

Ada beberapa kes kini yang melibatkan sebilangan bekas menteri dan anggota pentadbiran yang dijatuhi hukuman penjara dan didenda berjuta ringgit tetapi masih bebas bergerak dan menjalankan pelbagai kegiatan politik termasuk tugasan Parlimen mereka. ${ }^{17}$ Konon mereka boleh begitu lantaran bicara rayuan belum selesai. Sebagai perbandingan,

16 Lihat misalnya kes Pendakwa Raya lwn. Chua Tien Chang 2019 MLJ 168. Salah satu isu dalam kes ini ialah sama ada bayaran denda RM1,800 yang telahpun dibayar boleh membatalkan keahlian Dewan Rakyat YB Tian Chua sebagai responden. Tian Chua, calon pilihanraya umum 2018, telah dihalang pencalonannya atas alasan beliau telah didapati bersalah dan didenda atas kesalahan di bawah s.4(1)(b) Akta Hasutan 1948. Walaupun penghakiman Y.A. Datuk Mohd Nazlan M. Ghazali mendapati Tian Chua tidak bersalah lantaran tiada terdapat kes prima facie, peluang bertanding responden kandas kerana lewat beroleh penghakiman.

17 Semasa artikel ini ditulis, tiga kes besar rasuah telah beroleh hukuman dari Mahkamah Tinggi: Kes Datuk Seri Tengku Adnan Tengku Mansor, bekas Menteri Wilayah Persekutuan dihukum bayar denda di bawah s.165 Kanun Keseksaan, RM2 juta lantaran menerima habuan rasuah dan satu tahun penjara: lihat Malay Mail 21 Disember 2020; pada 3 Februari 2021 Tan Sri Isa Samad, bekas Pengerusi FELDA/Menteri Besar Negeri Sembilan dijatuhi hukuman enam tahun penjara dan RM15.45 juta denda susulan kes rasuah pembelian hotel di Sarawak - lihat Laporan Bernama 3 Februari 2021; terdahulu 28 Julai 2020, bekas Perdana Menteri Datuk Sri Mohd Najib Tun Razak dihukum penjara 12 tahun dan denda RM210 juta sabit kesalahan rasuah syarikat SRC, salah satu cabang korporat 1MDB yang skandalnya melibatkan financier licik, Jho Low dan kes ini tersebar luas di seluruh dunia: lihat The Star 28 Julai 2020. 
jika seseorang penjawat awam berada dalam situasi perundangan yang sama dia tetap digantung kerja di bawah Peraturan Am (General Orders).$^{18}$ Kenapa wujud, susulan kesalahan jenayah rasuah, misalnya, perbezaan layanan antara penjawat awam dengan Ahli Yang Berhormat?

Jawapannya, penjawat awam itu terikat dengan undang-undang dan peraturan seperti Perintah Am (yang diperbuat di bawah kuat kuasa Perkara 132 Perlembagaan Persekutuan), YB Ahli Parlimen atau YB ADUN merangkap Anggota Pentadbiran tiada tertakluk kepada penentuan hadangan kebebasan yang sama. Keadaan ini menambahkan lagi kekuatan hujah betapa pentingnya ahli-ahli Yang Berhormat dan anggota pentadbiran dikenakan layanan yang sama: manakala seseorang YB itu didakwa atau dijatuhi hukuman penjara atau denda atau keduaduanya sekali yang tertakluk kepada proses rayuan, wajib digantung khidmatnya sehingga selesai perbicaraan atau proses rayuannya.

Malah terbaik jugajika apa-apa anugerah bintang kebesaran seseorang yang bersalah di sisi undang-undang ditarik balik oleh mana-mana pihak berkuasa anugerah peringkat negeri dan persekutuan. ${ }^{19} \mathrm{Jika}$ ini tidak dilakukan, seolah-olah kerajaan dan sultan bersubahat 'tutup mata sebelah' terhadap jenayah.

Secara jelasnya semasa berada dalam sidang sesuatu mesyuarat DUN atau Parlimen, mereka memang tertakluk dan dikawal di bawah Peraturan Mesyuarat (Standing Orders) masing-masing. Di Dewan Rakyat dan di Dewan Negara, Peraturan Mesyuarat diwujudkan semenjak 1959 lagi bersekali dengan pelbagai pindaan yang diperbuat semenjak tahun itu. Di peringkatnegeri masing-masing Yang Berhormat ADUN tertakluk kepada Peraturan Mesyuarat DUN masing-masing. Malangnya mereka tidak diawasi di bawah tatacara khidmat semasa berada di khalayak atau semasa berkhidmat di kawasan masing-masing. Berbeza halnya dengan penjawat perkhidmatan awam. Semua kakitangan kerajaan

18 Bab B Peraturan Tatatertib dalam Perintah 'Am Perkhidmatan Awam Malaysia $<$ www.jpa.gov.my>.

19 Pada 9 Februari 2021 sudah terbit berita bahawa ada usaha atau langkah yang bakal diambil untuk menarik balik anugerah bintang kebesaran PSM yang membawa gelaran Tan Sri kepada bekas Peguam Negara Tommy Thomas susulan beberapa pendedahan yang ditulisnya dalam bukunya My Story: Justice in the Wilderness (Petaling Jaya, SIRD, 2021). Pada tahun 2014 Sultan Selangor dilaporkan menarik balik anugerah Dato' Seri daripada Datuk Seri Anwar Ibrahim lanjutan kepada reaksi Anwar yang kononnya menyalahkan Istana kerana enggan melantik isterinya Dr Wan Azizah Wan Ismail sebagai Menteri Besar Selangor: Malaysia Now (5 Februari 2021) <https://www.malaysianow.com/berita/2021/02/05/usaha-untuk-tarik-balikgelaran-tan-sri-tommy-thomas-dimulakan/>. 
daripada pembantu pejabat hingga ke Ketua Setiausaha Negara, mereka ditakluki Perintah Am yang dikuatkuasakan semenjak 1948 lagi hasil positif pemerintahan penjajahan British.

Dengan tiadanya sistem penguatkuasa etika yang mengawal dan mendisiplinkan wakil rakyat selaku ahli-ahli Yang Berhormat Parlimen dan DUN, muncul pada masa ini keadaan terbiar dari sudut peraturan danundang-undang. Lantaran ketiadaan tatacara khidmat dan kelakuan inilah yang kini harus dititikberatkan supaya prinsip keluhuran undangundang terjamin. Dari segi Perlembagaan Persekutuan sahaja sudah ada bedanya jika hal ini diperhatikan dari implikasi peruntukan kesamaan taraf di bawah Perkara 8(1):

Semua orang adalah sama rata di sisi undang-undang dan berhak mendapat perlindungan yang sama rata di sisi undang-undang.

Dengan berkuat kuasa Perkara 8 sahaja sudah mewajibkan pihak berkuasa dan pihak-pihak berkepentingan dalam bidang tugas legislatif untuk mengemas kini ketiadaan sama rata yang mencakupi di bawah Perkara 8 Perlembagaan Persekutuan itu. Sementelahan lagi, amplifikasi di bawah Perkara 8(2) pula menghalang apa-apa bentuk diskriminasi yang dicetuskan daripada perbezaan kulit, kaum, agama, keturunan, jantina dan tempat lahir. Namun, tampaknya persoalan seperti ini jarang kali memperoleh penentuan khasnya daripada pengamal siasah kita.

\section{Etika legislatif}

Etika legislatif yang dimaksudkan di sini harus terbahagi kepada dua: pertama, tatacara khidmat yang mengandungi dan menentukan apa-apa yang boleh dibuat dan apa yang tidak boleh dibuat sebagai YB Anggota Parlimen dan YB ADUN termasuk menteri, ketua menteri serta anggota exco masing-masing semasa bertugas harian. Seperti yang dihuraikan di atas, tatacara khidmat semasa di lapangan bersama-sama rakyat atau dalam persekitaran tanggungjawab wakil rakyat sangat memerlukan peraturan tetap dalam bentuk buku tangan (Handbook) Etika Wakil Rakyat. Pada asasnya mesti ada sistem akauntabiliti, ketelusan dan integriti dalam urusan membantu rakyat, cara dan kaedah agihan faedah pembangunan, pertembungan atau konflik kepentingan, penyimpanan rekod dan butiran asas, pentadbiran politik dan bukan politik seterusnya hal-hal sampingan berkaitan dengan derma politik, hubungan dengan pentadbir kerajaan, ketua-ketua jabatan, cara melayani aduan atau rungutan serta hal-hal berunsur rasuah dan salah guna kuasa. 
Kedua adalah bagi YB-YB yang bersidang di Dewan Legislatif masingmasing memang sudah sedia ada Peraturan Mesyuarat (PM) atau Standing Orders (SO) yang berkuat kuasa melalui kuasa Speaker. Cuma persoalannya adakah SO atau PM tersebut memadai keberkesanannya? Daripada tinjauan rambang yang dilakukan, beberapa kes berkaitan 'kelakuan yang tidak bersifat parliamentari' (unparliamentary behaviour) di Dewan Rakyat pada tahun 2018-2019, jelas bahawa tindakan tegas belum lagi menjadi amalan. ${ }^{20}$ Elemen yang jarang diperakukan ialah Peraturan Mesyuarat Dewan-Dewan Legislatifitu ialah undang-undang dalaman yang tidak boleh dicabar di mahkamah atas kedaulatan legislatif Parlimen dan DUN.

Pada tahun 2018 boleh dikesan tiga ucapan Ahli-ahli YB yang jelas bersifat unparliamentary ${ }^{21}$ atau bertembung dengan perlakuan waras di sesebuah Dewan Legislatif. Khususnya menggunakan perkataan mencarut atau bahasa kasar dan biadab tercatat dalam laporan Hansard ${ }^{22}$ Dewan Rakyat khasnya tanggal 2018. Persoalan ini harus diapungkan untuk pemerhatian semua pihak yang dianggap pemegang taruh (stakeholders). Pemegang taruh terbesar ialah rakyat yang dikhidmati dan undang-undang negara selain pihak berkuasa sepertiSpeaker atau Yang di-Pertua Dewan masing-masing. Apabila dengan jelas tiada didapati apa-apa peraturan yang lebih tegas bagi menjalankan tanggungjawab wakil rakyat yang bertauliah, akan timbul isu-isu keadilan, cabulan urus tadbir atau perkara-perkara keutamaan bagi menjalankan atau tidak menjalankan khidmat asas sebagai YB.

Memang ada pihak yang berpendapat bahawa tiada perlunya diadakan Perintah Am bagi politisyen yang berkhidmat sebagai wakil rakyat atau anggota legislatif sesebuah Dewan itu. Namun, mereka dalam golongan ini tidak pula menghuraikan persoalan; mengapa tidak? Lantaran semua Ahli Parlimen dan ADUN dibayar gaji serta elaun mereka oleh rakyat, amat setimpal jika apa-apa pencabulan terhadap imej dan reputasi

20 Undang-undang tambahan kepada Akta Suruhanjaya Perkhidmatan Awam Penggal 83.

21 Di United Kingdom apa yang dianggap sebagai bahasa tidak bersifat santun atau unparliamentary language di Dewan Parliamen ada dihuraikan di para 21:21 dalam buku D. Natzler dan M. Hutton, Erskine May's Treatise on The Law, Privileges, Proceedings and Usage of Parliament (25th edn, Butterworths, Lexis Nexis, 2019). Di sisi Peraturan Mesyuarat 36(4) Dewan Rakyat Malaysia, Ahlinya dilarang menggunakan bahasa biadab. Bagi Dewan Negara lihat Peraturan Mesyuarat 35.

22 Hansard ialah nama rasmi Laporan Persidangan Dewan Legislatif. Ia nama pelapor asal prosiding Parlimen Inggeris yang paling produktif dan berkesan. 
tertinggi Dewan Parlimen dan DUN wajib dihindarkan demi menjaga reputasi kenegaraan yang juga begitu tinggi di mata rakyat.

\section{Kemanusiaan dan etika}

Kemanusiaan tidak pernah jauh daripada kehidupan beretika sama ada etika yang terasas secara tradisional seperti yang terkandung dalam amalan budaya, adat, asuhan agama etnik atau dalam bentuk etika yang formal seperti Kod Etika Bagi Anggota Pentadbiran ${ }^{23}$ yang dikuatkuasakan melalui Kabinet Kerajaan Malaysia. ${ }^{24}$ Kod etika tersebut khusus bagi para Menteri Kabinet yang secara kebetulan pula tidak pernah diwajibkan untuk berkursus atau diberi kursus selaku anggota pentadbiran. Istilah anggota pentadbiran di sini harus dimengertikan sama seperti yang diperuntukkan di bawah Akta Interpretasi 1948 dan Perkara 160(2) Perlembagaan Persekutuan. Jawatan-jawatan seperti Perdana Menteri, Timbalan Perdana Menteri (yang tiada diberi sebutan dalam Perlembagaan Persekutuan), Menteri, Timbalan Menteri, Setiausaha Parlimen dan Setiausaha Politik di peringkat Persekutuan dan Menteri Besar/ Ketua Menteri serta Ahli-ahli Exco dalam Kerajaan Negeri semuanya mengendalikan urusan dan pentadbiran negara. Justeru mereka mesti, selaras dengan undang-undang negara yang sedia ada berkaitan dengan jenayah, mematuhi secara insaf dan terbuka akan etika kerja masing-masing. Selaras itulah diwujudkan Kod Etika Bagi Anggota Pentadbiran pada tahun 2004.

Perdana Menteri, Dr Mahathir Mohamad selaku ketua kerajaan pada masa itu sering mengingatkan anggota Kabinetnya supaya mematuhi etika tersebut agar kepercayaan rakyat terhadap anggota pentadbiran menjadi teras perkhidmatan yang baik dan disegani. Perkara-perkara seperti tanggungjawab bersama (Collective Responsibility), ${ }^{25}$ tegahan

23 Dalam pentadbiran Kabinet pimpinan kebanyakan Perdana Menteri terdahulu seperti Tunku Abdul Rahman, Tun Abdul Razak, Tun Hussein Onn dan Tun Dr Mahathir Mohamad, setiap Menteri dibekalkan senaskhah Kod Etika Bagi Anggota - Anggota Pentadbiran, Januari 2004, Jabatan Perdana Menteri untuk diteliti dan dipatuhi.

24 Untuk rujukan sistem Kabinet di Malaysia sila lihat R. Yatim, 1Malaysia Cabinet: Reflecting on Cabinet Governing (Kuala Lumpur, Endowment Publications, 2005). Edisi awalan buku ini Cabinet Governing in Malaysia memuatkan naratif Kerajaan Dr Mahathir Mohamad (1995).

25 Kod Etika Bagi Anggota Pentadbiran 2004 (Putrajaya, Jabatan Perdana Menteri, 2004) s 1. 
berniaga ${ }^{26}$ perisytiharan harta, ${ }^{27}$ percanggahan kepentingan (Conflict of interest) ${ }^{28}$ menjaga kerahsiaan kerajaan, kewaspadaan memimpin badanbadan bukan kerajaan (NGO) ${ }^{29}$ tatakelakuan diri dan diri pasangan ${ }^{30}$ serta beberapa perkara pokok yang lain. Penulis yang memulakan karier politiknya pada 1974 di bawah pimpinan Tun Abdul Razak Hussein (1970-1976), disusuli pimpinan Tun Hussein Onn (1976-1981) sebelum pentadbiran Tun Dr Mahathir Mohamad (1981-2003) dapat menelusuri perkembangan etika ini musim ke musim dan semua menteri di bawah pimpinan Perdana Menteri tersebut akur belaka kepada inti sari kodkod etika yang dikemukakan oleh mereka.

\section{Etika Yang Berhormat Wakil Rakyat (EYBWR)}

Etika yang dimaksudkan dengan EYBWR di sini ialah peraturan urusan rasmi Yang Berhormat wakil rakyat yang seharusnya berteraskan amalan baik budi dan nilai-nilai murni atau tatakelakuan yang layakmewujudkan pemimpin kelas satu, berhemah dan berpotensi mencipta sifat-sifat cemerlang pada masa depan. Beretika bererti berfungsi dengan cara dan kaedah yang luhur, yang berperaturan dan yang memupuk budaya tinggi. Kelakuan atau sistem hidup yang beretika bererti hidup yang sentiasa dipagari nilai-nilai murni yang seterusnya berupaya menjadi satu sistem berteraskan budi luhur. Malah etika merupakan prinsip-prinsip moral yang membedung kelakuan atau gerak laku terpuji. Tanpa etika hidup yang diorientasikan nilai-nilai murni, seseorang itu tidak mudah berjaya menampilkan kehidupan bertamadun tinggi.

Oleh sebab Parlimen merupakan gedung legislatif yang mencipta pemimpin negara, semestinya setiap Ahli Parlimen itu pula terdiri daripada manusia yang terdidik bukan sahaja dari sudut kelayakan yang bertauliah seperti berdiploma, berijazah tetapi juga kelayakan yang tuntas murni dan berjiwa besar yang dilengkapi budaya tinggi. Kelakuannya, keterampilannya, kebolehan atau kepetahannya dalam urusan berbahasa dan berkomunikasi - semua kebolehan dan sifat ini hendaklah ada pada setiap Ahli Parlimen dan ADUN. Apakah sebabnya? Hal ini sebabkan oleh para pemimpin ini ialah pilihan rakyat dari

26 ibid s 2.

27 ibid s 3.

28 ibid $\mathrm{s} 4$.

29 ibids 5.

30 ibid s 8 dan 9. 
bawah. Mereka merupakan ayam tambatan rakyat, juara dalam halhal memperjuangkan kepentingan rakyat dan nilai-nilai kemanusiaan terulung.

Gelanggang tempat para pemimpin terkumpul seperti Parlimen, DUN, Senat Universiti, Persidangan Adat atau Dewan Pendidik, misalnya, dianggap institusi tertinggi kepemimpinan. Institusi-institusi inilah yang layak dianggap sebagai kancah atau tuangan hidup berbudi dan berjasa.

Dalam konteks keluhuran kelakuan yang beretika itulah terkandung sahsiah atau karakter seseorang. Daripada anak hingga kepada ibu bapa; daripada guru hingga kepada penghulu seterusnya hingga kepada pemimpin - etika kehidupan sentiasa membedung mereka. Lantaran itu, dikatakan jika guru kencing berdiri, murid akan kencing berlari; bagaimana ibu bapa berperangai begitulah anak-pinaknya ketika dewasa kelak; dalam konteks masyarakat tradisional dahulu kala - kaedah penghulu berkhidmat memercikkan sifat kepimpinannya kepada anak buah di bawah pimpinannya. Akan terasa kebenaran melalui peribahasa ini, pemimpin seranting tinggi, selangkah di hadapan.

Kelakuan keji seperti yang dirakam dalam naratif di atas tidak beroleh tindakan setimpal pada masa perlakuannya. Dalam pada itu Ahli-ahli Parlimen kita sudah jauh ke hadapan dengan perilaku atau gelagat diri yang agak jauh dari sifat terpuji sebagai pemimpin rakyat. Jika pemimpin remaja meniru pula akan gejala kurang baik itu, negara akan kerugian. Peraturan Mesyuarat Dewan yang terpakai di Dewan Rakyat dan Dewan Negara ada lunas sorotannya kepada House of Commons dan House of Lords. Pendirian 'gentleman' anggota kedua-dua Dewan Legislatif Inggeris itu memang wajar diteladani dan Peraturan Mesyuarat Dewan Rakyat serta Dewan Negara membenarkan nas amalan daripadanyajika diperlukan dari semasa ke semasa.

Daripada huraian am di atas dan daripada realiti yang ada dalam buku laporan Hansard ternyata proses mundur atau deterioration sudah meresap ke dalam tingkah laku, ucapan dan gaya berdebat di Parlimen Malaysia. Sebelum menjadi kritikan besar lagi bahaya, perubahan gerak kerja legislatif dalaman dan luaran harus dimulakan.

Sukar untuk membuat penentuan yang tepatberkaitan dengan gelagat, kelakuan atau perbuatan yang tergolong kepada senarai kelakuan negatif di atas. Yang nyata kini ialah rekod perbuatan itu menimbulkan suasana, imej dan kesan yang rata-rata tidak menyenangkan kerana keji dan biadab. Sifat biadab dan kurang ajar hendaknya sesekali tidak dikenakan kepada pemimpin kita. 


\section{Penutup}

Latihan yang diterima oleh seseorang wakil rakyat itu biasanya daripada parti masing-masing sahaja. Parlimen tiada menyajikan latihan sebagai Ahli Parlimen. Latihan biasa seseorang wakil rakyat banyak terkait perlembagaan parti, cara dan kaedah hendak memberi sokongan kepada pucuk pimpinan dan sebagainya. Amat jarang dilaksanakan kursus Perlembagaan Persekutuan atau negeri, hak-hak asasi manusia yang terkandung di dalamnya; batas serta implikasi kuasa politik dan pentadbiran, cara mempelajari Peraturan Mesyuarat atau Standing Orders Dewan, kaedah-kaedah melanjutkan tatacara hidup berbudi, pantang larang sebagai pemimpin, keterampilan, integriti dan sebagainya. Pegawai kerajaan di bawah Jabatan Perkhidmatan Awam (JPA) mempunyai pusat latihan mereka di Institut Tadbiran Awam Negara (INTAN), bagi ahli-ahli politik yang semuanya ingin menjadi pemimpin besar negara dan negeri mereka tidak ada satu institut wajib untuk diasuh sebagai pengkhidmat tulen negara. Sesungguhnya dokumen-dokumen utama inilah yang wajib difahami dan dipatuhi selain Rukun Negara yang sering tertinggal dan ditinggalkan dalam arus perdana perjuangan para wakil rakyat. Semua wakil rakyat perlu diwajibkan menjalani sekurang-kurangnya enam bulan latihan dan serlahan tatanegara yang bolehlah disegmenkan mengikut jadual lima tahun seseorang itu menjadi wakil rakyat. Jadikan ini sebagai tuntutan dan kuasa perundangan supaya tiada yang ponteng. Jika ponteng atau 'curi tulang' YB itu wajib dikenakan tindakan disiplin legislatif di bawah Akta 347 tersebut di atas. Tentunya cadangan ini boleh dilaksanakan oleh kerajaan yang kukuh kedudukannya di Parlimen.

Pemerhatian dan cadangan Kod Etika Legislatif atau Kod Etika Wakil Rakyat ini diketengahkan dalam usaha membina kumpulan pemimpin legislatif masa depan negara yang disegani, yang layak dicontohi melalui kepentingan budaya tinggi yang ciri dan sifatnya wajib diamalkan oleh setiap anggota Parlimen dan ADUN. Saranan ini dirasakan amat sesuai dan perlu bukan sahaja bagi seseorang wakil rakyat di Dewan Rakyat atau di Dewan Negara tetapi juga bagi anggota mana-mana DUN. Wakil Rakyat semua parti bersatu membina negara dalam latihan dan asuhan anak Malaysia.

Yang penting ialah etika tersebut mengandungi butiran khusus tentang:

1. Tatacara kelakuan yang terperinci serta sistem disiplin,

2. Memahami struktur utama kenegaraan dan undang-undang asas negara, 
3. Asas-asas Perlembagaan Persekutuan dan negeri,

4. Mempromosi Rukun Negara,

5. Perpaduan kaum yang tidak boleh diambil ringan,

6. Kandungan pencirian moral,

7. Keterampilan diri,

8. Cara berkomunikasi terbaik,

9. Latihan ledakan budi atau virtue,

10. Berhemah dengan semua golongan,

11. Kaedah menghormati pandangan dan pendapat orang lain,

12. Asuhan integriti,

13. Kaedah meningggikan intelektualiti sebagai pemimpin,

14. Sifat patuh kepada peraturan dan undang-undang,

dan topik-topik lain yang berkaitan dan relevan kepada setiap orang wakil rakyat yang dipanggil YB.

Etika tersebut wajib dipatuhi melalui mekanisme peraturan di bawah jagaan Parlimen atau DUN masing-masing. Dirasakan saluran terbaik adalah di bawah bab membuat peraturan di bawah Akta 347, yakni Akta Majlis Parlimen (Keistimewaan dan Kuasa) 1952 atau memadai melalui kuasa mana-mana Jawatankuasa Khas Dewan Rakyat / Dewan Negara serta DUN yang sedia ada. Walaupun boleh dimajukan melalui kuasa Petua Yang di-Pertua atau melalui usul dari mana-mana menteri kerajaan, kesan imperatifnya tidaklah sama, justeru ia mesti beroleh penguatkuasaan undang-undang atau peraturan khidmat legislatif baru.

Walau bagaimanapun, dari segi Dewan Negara, usul penubuhan Kod Etika Legislatif ini, atau lebih baik Kod Etika Wakil Rakyat boleh dilakukan atas suatu usul langsung di bawah PM13(2) ${ }^{31}$ Dewan Negara.

31 PM 13(2): Majlis Mesyuarat dengan dibawa usul yang tidak berkehendak dikeluarkan pemberitahu boleh memutuskan hendak menjalankan mana-mana jua urusan dengan tidak mengikut aturan yang telah ditetapkan. Usul ini hendaklah didahulukan daripada urusan-urusan lain dan hendaklah diputuskan dengan tidak boleh dipinda atau dibahas. Nota: Peruntukan kuasa ini tiada pada PM Dewan Rakyat di mana di Dewan itu hanya Menteri dibenarkan mengemukakan usul tertakluk kepada kebenaran oleh Speaker/YDP. 
Malangnya peruntukan yang sama tiada didapati pada PM14(2) Dewan Rakyat. ${ }^{32}$ Semua anggota whip atau unit disiplin parti politik masingmasing wajar diwajibkan mengawas dan mengamalkan prinsip amalan terbaik (best practices principle). Juga harus disarankan bagi Parlimen mengadakan kursus-kursus 'baiki prestasi' dari semasa ke semasa. Dalam kursus demikian Yang di-Pertua/ Speaker, Perdana Menteri/ Timbalan Perdana Menteri, menteri atau pensyarah-pensyarah khas bolehlah menginduksi YB-YB kita. Serlahan kursus sedemikian amat wajar dilibatkan YB ADUN supaya nas bina negara Malaysia terselaras. Yang terpenting ialah keberkesanan Tuan Yang di-Pertua (Speaker) Dewan masing-masing yang sedia mempunyai kuasa pengawasan dalam sidang masing-masing. Dalam bahasa warisannya beliau mempunyai sifat dan kuasa kendur berdenting-denting, tegang berjela-jela.

\section{Rujukan}

Dicey A.V., Introduction to the Study of the Law of the Constitution (Oxford University, 1886).

Jabatan Perdana Menteri, Kod Etika Bagi Anggota-Anggota Pentadbiran (Jabatan Perdana Menteri, 2004).

Natzler D. dan Hutton M., Erskine May's Treatise on The Law, Privileges, Proceedings and Usage of Parliament (25th edn, Butterworths, Lexis Nexis, 2019).

Peraturan Tatatertib dalam Perintah 'Am Perkhidmatan Awam Malaysia.

Thomas T., My Story: Justice in the Wilderness (Petaling Jaya, SIRD, 2021).

Yatim R., 1Malaysia Cabinet: Reflecting on Cabinet Governing (Kuala Lumpur, Endowment Publications, 2005).

32 Lantaran inilah masalah timbul dalam isu hendak membawa sesuatu usul Tidak Percaya (Non-Confidence Motion) untuk dikemukakan oleh Ahli selain seseorang Menteri. Di bawah PM 13(2) Dewan Negara usul tidak percaya, misalnya boleh dilakukan di sisi peruntukan PM tersebut. 